\title{
Pembelajaran Lingkungan Berbasis Kearifan Lokal dengan Model Experiential Learning
}

\author{
Bunga Dwi Immaniar ${ }^{1}$, Sumarmi ${ }^{1}$, I Komang Astina ${ }^{1}$ \\ ${ }^{1}$ Pendidikan Geografi-Universitas Negeri Malang
}

\section{INFO ARTIKEL}

Riwayat Artikel:

Diterima: $07-05-2019$

Disetujui: 27-05-2019

\section{Kata kunci:}

learning environment; experiential learning model; local culture; pembelajaran lingkungan; model experiential learning; kearifan lokal

\author{
Alamat Korespondensi: \\ Bunga Dwi Immaniar \\ Pendidikan Geografi \\ Universitas Negeri Malang \\ Jalan Semarang 5 Malang \\ E-mail: bungadwiimmaniar@gmail.com
}

\begin{abstract}
Environmental damage that occurs on earth is caused by human activities. Human activities that use the environment excessively cause the environment to be damaged. These activities describe human attitudes and behavior that are low in environmental preservation. Low human behavior towards the environment can be improved through education through environmental learning. Environmental learning takes the form of real learning activities to gain knowledge through everyday life. Environmental learning in everyday life is obtained through local wisdom to improve environmental care behavior. The purpose of this study was to determine the participation of students using local wisdom-based environmental learning through the Experiential Learning model. The study design included the participation of students using local wisdom-based environmental learning through the Experiential Learning model.
\end{abstract}

ABSTRAK

\begin{abstract}
Abstrak: Kerusakan lingkungan yang terjadi di bumi disebabkan oleh aktivitas manusia. Aktivitas manusia yang memanfaatkan lingkungan secara berlebihan menyebabkan lingkungan menjadi rusak. Aktivitas tersebut menggambarkan sikap dan perilaku manusia yang rendah dalam pelestarian lingkungan. Perilaku manusia yang rendah terhadap lingkungan dapat diperbaiki melalui pendidikan melalui pembelajaran lingkungan. Pembelajaran lingkungan berupa kegiatan belajar secara nyata untuk memperoleh pengetahuan melalui kehidupan sehari-hari. Pembelajaran lingkungan dalam kehidupan sehari-hari didapatkan melalui kearifan lokal untuk meningkatkan perilaku peduli lingkungan. Tujuan penelitian ini untuk mengetahui partisipasi peserta didik menggunakan pembelajaran lingkungan berbasis kearifan lokal melalui model Experiential Learning. Desain penelitian terdapat partisipasi peserta didik yang menggunakan pembelajaran lingkungan berbasis kearifan lokal melalui model Experiential Learning.
\end{abstract}

Kerusakan lingkungan menjadi hal yang sulit dipisahkan dalam kehidupan masyarakat. Kehidupan masyarakat yakni aktivitas manusia merupakan penyebab terjadinya peristiwa bencana dan kerusakan lingkungan. Aktivitas atau kegiatan tersebut menggambarkan bahwa manusia memiliki tingkat kepedulian yang rendah pada kelestarian lingkungan. Selaras dengan pernyataan tersebut, (Sriyanto, 2007) kerusakan lingkungan terjadi dimana-mana disebabkan masyarakat yang tidak peduli, memiliki kesadaran yang minim dan tidak berfungsinya hukum secara maksimal. Kesadaran yang minim pada masyarakat terhadap lingkungan menyebabkan lingkungan menjadi rusak.

Kesadaran yang minim terhadap pelestarian lingkungan dapat dirubah menjadi lebih baik melalui pendidikan dengan pembelajaran lingkungan. Selaras dengan pernyataan tersebut, (Juairiah, 2014) Pembelajaran lingkungan merupakan objek belajar yang digunakan sebagai pengalaman nyata dalam kegiatan belajar sehingga dapat belajar secara mandiri maupun kelompok, memperoleh data secara akurat dan pastinya dapat mengamati langsung. Lingkungan sebagai objek belajar yang nyata baik dilakukan secara mandiri ataupun kelompok untuk memperoleh pengetahuan.

Pembelajaran lingkungan yang nyata dalam melestarikan lingkungan didapatkan peserta didik melalui kehidupan disekitarnya. Kehidupan sekitar yang dapat mendukung pelestarian lingkungan ialah melalui kearifan lokal. Kearifan lokal merupakan nilai-nilai atau norma yang berlaku bahkan dipercaya dalam suatu masyarakat hingga saat ini (Gunawan, 2014). Nilai atau norma yang kebenarannya dipercayai sehingga menjadi anutan pada masyarakat dalam bertingkah laku sehari-hari dan dengan baik diterapkan maka akan memiliki kesadaran yang tinggi dalam menjaga lingkungannya. Kesadaran yang tinggi terhadap lingkungannya dapat ditonjolkan oleh manusia melalui perlakuannya terhadap suatu benda atau objek. Benda atau objek tersebut dapat berupa apapun yang ada disekitarnya baik benda mati ataupun hidup. 
Pembelajaran lingkungan berbasis kearifan lokal menjadi peran penting dalam proses belajar. Pembelajaran tersebut menuntut peserta didik untuk memperoleh pengetahuan melalui proses belajar dengan objek yang nyata dalam kehidupan disekitar pembelajar. Menurut (Pakpahan, 2017) langkah awal yang diberikan untuk proses pembentukan sikap dan perubahan perilaku pelajar agar peduli kepada lingkungan ialah dengan memberikan pengetahuan. Pengetahuan yang diperoleh peserta didik melalui pembelajaran lingkungan berbasis kearifan lokal dapat membentuk perilaku peduli terhadap lingkungan.

Perilaku yang menunjukkan peduli terhadap lingkungan dalam pelestarian lingkungan dapat terwujud atas usaha guru dalam menggabungkan atau menyatukan keadaan yang nyata dengan materi. Menurut (Afriani, 2018) pembelajaran kontekstual merupakan kegiatan belajar yang bertujuan untuk memotivasi peserta didik menerapkan kedalam kehidupannya dengan pengetahuan yang dimiliki atau teori yang telah didapatkan. Hal tersebut dapat mereka implementasikan berkat bantuan dari guru. Peserta didik yang belajar secara kontekstual dalam proses pembelajarannya akan mendapatkan kemistri dengan lingkungan sehingga mudah terbentuk perilaku peduli pelestarian lingkungannya. Pembelajaran atau proses kegiatan belajar tersebut dapat diterapkan melalui model Experiential Learning.

Model Experiential Learning merupakan kegiatan belajar untuk berpikir dan melakukan atau berbuat berdasarkan pikiran yang didapatkan dari pengalaman. Menurut (Hariri, 2017) Experiential Learning merupakan model kegiatan belajar yang aktif berpikir untuk menemukan sesuatu melalui pengalaman yang telah dilalui atau diperoleh. Seseorang dihadapkan dengan peristiwa kemudian melakukan tindakan secara aktif maka dapat dikatakan orang tersebut dapat jauh lebih baik dalam belajar. Hal tersebut dikarenakan peserta didik berpikir degan aktif mengenai hal yang dipelajarinya dalam setiap proses belajar sehingga jika dihadapkan sebuah peristiwa nyata mereka dapat menerapkannya.

Experiential Learning merupakan kegiatan belajar peserta didik untuk meningkatkan kemandirian belajarnya. Peningkatan kemandirian belajar peserta didik tersebut dikarenakan student centered learning atau kegiatan belajar yang berpusat pada peserta didik. Pembelajaran yang focus kepada peserta didik dapat memberikan kebebasan pembelajar untuk mendapatkan kesempatan menyelidiki sendiri ilmu pengetahuannya agar kualitas peserta didik meningkat dan pengetahuan menjadi semakin dalam (Antika, 2014). Perubahan peserta didik tidak hanya terletak pada pengetahuannya dan mengaplikasikan dengan baik.

Experiential Learning merupakan model yang mengikutsertakan peserta didik berinteraksi langsung dengan lingkungan untuk mendapatkan pengetahuan melalui pengalaman. Model pembelajaran tersebut menggunakan masalah melalui pengalaman nyata sebagai tahap awal untuk menstimulasi pengetahuan dan pemahaman secara nyata. Menurut (Dewi, 2018) proses belajar yang dapat membangkitkan pengetahuan, sikap, dan keterampilan melalui pengalaman nyata merupakan serangkaian proses untuk merangsang pembelajar agar aktif. Serangkaian proses belajar tersebut menciptakan kegiatan belajar yang menyenangkan dan berarti bagi peserta didik.

Model Experiential Learning dapat membangun pengetahuan peserta didik sebelumnya dengan yang baru mereka dapat melalui kegiatan belajar. Pengetahuan tersebut tidak hanya di dalam kelas dengan memberikan materi, akan tetapi dapat menimbulkan kesadaran dan menampakkan dengan nyata keterampilan yang dimiliki agar dapat menjaga lingkungan serta hidup secara berdampingan. Hal tersebut dikarenakan peserta didik berinteraksi langsung dengan benda yang diamati dalam kegiatan observasi lapangan sehingga peserta didik dapat peluang banyak dan kesempatan untuk mengkaji situasi lingkungan disekitar. Pengintegrasian Experiential Learning dengan pelestarian lingkungan pada mata pelajaran Geografi yang tepat untuk diaplikasikan. Hal ini dikarenakan pelestarian lingkungan mampu menyampaikan pengalaman yang banyak dan bermacammacam. Pengalaman tersebut antara lain ialah pengetahuan dan pemahaman yang dapat menggerakkan perilaku pelestarian lingkungan. Peserta didik dapat mengembangkan pengetahuan dan keterampilannya untuk terjun dalam melestarikan lingkungan.

\section{METODE}

Quasi experiment atau eksperimen semu menjadi desain penelitian dalam penelitian ini. Peneliti melaksanakan penelitian untuk mengetahui pembelajaran lingkungan berbasis kearifan lokal dengan model Experiential Learning. Eksperimen semu menjadi alasan dalam penelitian ini dikarenakan subjek penelitian sepenuhnya tidak mampu dikendalikan oleh peneliti. Dua kelas yakni eksperimen dan kontrol menjadi subjek penelitian, peserta didik kelas X IS 1 (eksperimen) dan X IS 3 (kontrol) SMAN 1 Giri Kabupaten Banyuwangi. Kelas eksperimen diberikan perlakuan dengan model Experiential Learning, perlakuan berbeda degan tanya jawab, ceramah, dan pemberian tugas terjadi pada kelas kontrol.

Instrumen angket sebagai perangkat dalam penelitian ini. Empat pilihan jawaban yang digunakan dalam angket, yakni Sangat Setuju (SS), Setuju (S), Tidak Setuju (TS), dan Sangat Tidak Setuju (STS). Angket tersebut dimodifikasi dan dikembangkan oleh (Maryuliana, Imam Much Ibnu Subroto, \& Sam Farisa Chairul Haviana, 2016). Dua data yakni primer dan sekunder menjadi sumber data yang digunakan dalam penelitian ini. Uji hipotesis dilakukan setelah data yang diperlukan telah terkumpul menggunakan independent sample t-test melalui SPSS for windows dengan taraf signifikan 0,05. 


\section{HASIL}

Data partisipasi peserta didik dalam pembelajaran lingkungan berbasis kearifan lokal didapatkan dari eksperimen dan kontrol. Hasil tersebut diperoleh dari nilai gain score yang diukur melalui angket berupa perilaku pelestarian lingkungan berbasis kearifan lokal. Hasil gain score ditampilkan dari rata-rata skor tiap kelas tabel 1.

Tabel 1. Rata-Rata Partisipasi Pembelajaran Lingkungan Peserta Didik

\begin{tabular}{lc}
\hline Kelas & Rata-rata \\
\hline Eksperimen & 28.35 \\
\hline Kontrol & 18.06 \\
\hline Selisih & 10.29 \\
\hline
\end{tabular}

Tabel 1 menunjukkan keputusan bahwa rata-rata skor diperoleh dari hasil gain score yaitu selisih dari pretest dan posttest. Hasil gain score menunjukan bahwa kelas eksperimen mempunyai nilai rata-rata lebih tinggi dibandingkan dengan kelas kontrol. Perbedaan sebesar 10,29 terlihat dari selisih perolehan skor antara eksperimen dengan kontrol. Hasil menunjukkan bahwa eksperimen memiliki partisipasi lebih baik terhadap lingkungan lebih baik daripada kelas kontrol. Kesetaraan rata-rata gain score disajikan pada gambar 1.

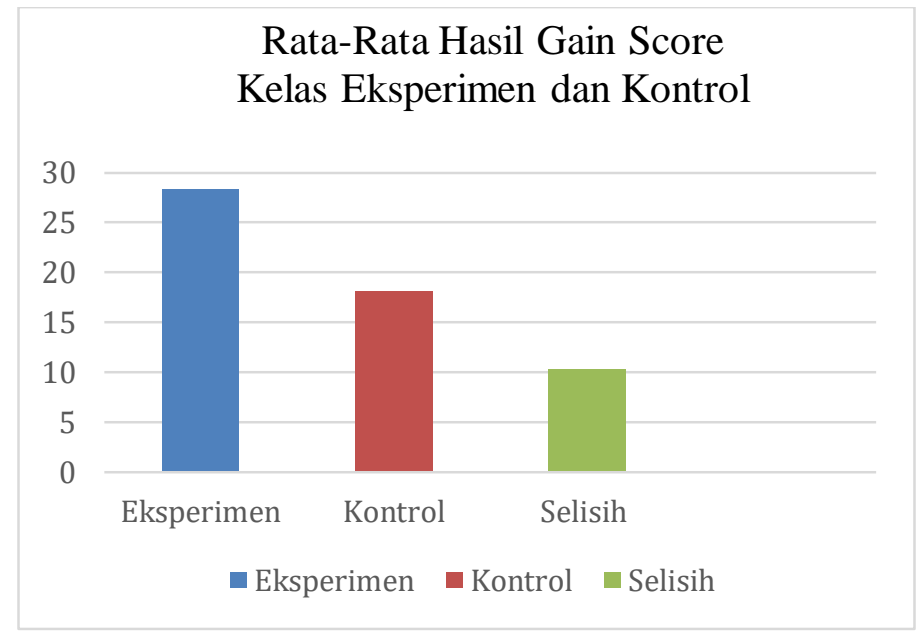

\section{Gambar 1. Kesetaraan Rata-rata Gain Score Kelas Eksperimen dan Kontrol}

Gambar 1 memperlihatkan bahwa terdapat perbedaan skor antara kedua kelas yakni eksperimen dan kontrol. Perbedaan yang terjadi disebabkan karena perlakuan yang diberikan berbeda antara kedua kelas tersebut. Kelas kontrol memiliki skor lebih sedikit karena pembelajaran hanya dilakukan dengan menggunakan tanya jawab, ceramah, dan penugasan. Kelas eksperimen menggunakan model pembelajaran yang menarik yakni Experiential Learning. Hasil yang didapatkan selanjutnya peneliti simpulkan bahwa kelas yang menggunakan model Experiential Learning memiliki pengaruh terhadap partisipasi peserta didik dalam pembelajaran lingkungan berbasis kearifan lokal. Hal ini ditampilkan dengan benar melalui hasil uji hipotesis dengan uji independent sample t-test yang menunjukan adanya pengaruh signifikan terhadap partisipasi pembelajaran lingkungan berbasis kearifan lokal. Pada tabel 2 disajikan hasil analisis agar lebih jelas yakni sebagai berikut.

Tabel 2. Uji Hipotesis Independent Sample t-test

\begin{tabular}{lcccccc}
\hline & & Levene's Test for Equality of Variances & \multicolumn{3}{c}{ t-test for Equality of Means } \\
\hline \multirow{2}{*}{ Gain Score } & F & Sig. & T & Df & Sig. (2-tailed) \\
\cline { 2 - 7 } & Equal variances assumed & .086 & .770 & 7.069 & 60 & .000 \\
\cline { 2 - 8 } & Equal Variances not assumed & & & 7.069 & 59.992 & .000 \\
\hline
\end{tabular}

Tabel 2 menampakkan hasil pada kolom Sig. 2-tailed sebesar 0,000. Hasil sebesar 0,000 $\leq 0,05$ memiliki arti ditolaknya HO. Terdapat pengaruh yang signifikan penggunaan model Experiential Learning terhadap pelestarian lingkungan merupakan penjelasan perihal ditolaknya HO. Nilai lebih baik ditunjukkan oleh peserta didik melalui partisipasinya terhadap pelestarian lingkungan daripada kelas kontrol. Hal tersebut mengindikasikan bahwa model pembelajaran pada kelas eksperimen lebih efektif untuk menumbuhkan partisipasi terhadap pembelajaran lingkungan berbasis kearifan lokal. 


\section{PEMBAHASAN}

Penelitian mengenai pembelajaran lingkungan berbasis kearifan lokal dengan model Experiential Learning memperoleh hasil yang sangat baik dalam melestarikan lingkungannya yang didapat dari kelas eksperimen, bila dibedakan dengan kelas kontrol. Hal tersebut nampak jelas dari data nilai rata-rata gain score yang didapat sebesar 28,35 untuk kelas eksperimen dan sebesar 18,06 untuk kontrol. Pembelajaran lingkungan berbasis kearifan lokal dengan model Experiential Learning untuk mengetahui partisipasi peserta didik dalam pelestarian lingkungan sudah pasti mempunyai pengaruh signifikan setelah teruji. Keterujian tersebut melewati uji hipotesis dengan Independent Sample T-Test sehingga mendapat nilai Sig. 0,000 (2-tailed) dengan artian kurang dari 0,05.

Kelas eksperimen dan kontrol memiliki perbedaan pada pengelolaan kelas dan model pembelajarannya. Model pembelajaran Experiential Learning sanggup menciptakan lingkungan yang lebih baik yang berasal dari partisipasi peserta didik dibandingkan dengan kelas kontrol. Menurut (Fatliani, 2014) menyatakan bahwa pembelajaran Experiential Learning mampu mendorong peserta didik untuk melakukan aksi nyata terkait pelestarian lingkungan serta aktif berpartisipasi. Kepedulian terhadap lingkungan merupakan perwujudan partisipasi untuk memberikan perilaku yang baik. Perilaku yang baik dilakukan setiap hari tanpa paksaan agar dapat hidup berdampingan dengan alam dengan wujud tindakan positif. Tindakan positif yang dimaksud ialah meningkatkan motivasi kesadaran manusia mengenai konservasi lingkungan, menarik industri wisata hijau atau lingkungan dan memperbaharui sumberdaya alam yang dapat terbarukan.

Hal tersebut karena kegiatan belajar Experiential Learning pada kelas eksperimen lebih kontekstual melalui pembelajaran lingkungan berbasis kearifan lokal dan pembelajar merasakan kebebasan dalam belajar. Kegiatan belajar yang prosesnya memanfaatkan lingkungan dengan kearifan lokal sebagai sumber belajar secara nyata untuk peserta didik. Kegiatan tersebut memiliki tujuan untuk memecahkan masalah pada observasi lapangan yang dilakukan dan melakukan kasi dalam penyelesaiannya. Aksi yang dilakukan merupakan sebuah perwujudan peserta didik terhadap lingkungan sekitar untuk menjaga kelestarian lingkungan berbasis kearifan lokal. Model Experiential Learning merupakan kegiatan belajar yang lengkap dan mendalam melalui pengamatan pada sumber belajar (lingkungan) terhadap masalah yang pasti untuk melakukan aksi.

Kegiatan pembelajaran tersebut membentuk kepekaan peserta didik agar sensitif mengenai kondisi lingkungan dari kegiatan observasi lapangan yang telah dilaksanakan. Pembelajaran yang terjadi terfokus pada aktivitas peserta didik atau student centered menciptakan keaktifan yang lebih dan fasilitator merupakan peran dari pendidik. Selaras dengan pendapat (Ardian, 2015) serangkaian aktivitas belajar bertujuan membentuk sikap, pengetahuan, perilaku dan peserta didik berpartisipasi aktif didalamnya. Serangkaian aktivitas belajar tersebut apabila diimplementasikan dengan benar maka akan terbentuk perilaku peduli lingkungan pada tiap-tiap individu dalam bentuk pelestarian lingkungan. Peneliti mendapati hasil observasinya bahwa peserta didik sangat bersemangat, aktif, dan turun tangan dalam penyelenggaraan kegiatan pelestarian lingkungan sebagai wujud menjaga lingkungan dalam lingkungan sekolah. Pelestarian lingkungan terbentuk atas partisipasi peserta didik menggunakan pembelajaran lingkungan berbasis kearifan lokal yaitu melakukan observasi lapangan langsung dengan kegiatan kearifan lokal didalamnya. Tahapan-tahapan pembelajaran Experiential Learning dan dengan penyelesaian artikel ilmiah yang didalamnya berisi mengenai aksi yang akan dilakukan peserta didik untuk melestarikan lingkungan. Aksi tersebut didapat oleh peserta didik melalui keputusan kelompok.

Wujud pelestarian lingkungan yang dilaksanakan peserta didik setelah dapat masalah di lingkungan sekitar yaitu dengan melakukan kegiatan kerja bakti, memungut dan membuang buangan pada tempat sampah, dan memperluas daerah resapan air dengan menanam tanaman. Kegiatan kerja bakti yang dilakukan dengan mengambil beberapa sampah dilokasi observasi lapangan dan membuang sampah pada tempat sampah. Penanaman pohon berjumlah lima pohon sengon ditanam peserta didik dibeberapa titik sekitar sumber air. Hal tersebut dilakukan untuk memperluas daerah resapan air.

Aksi atau kegiatan yang dilakukan peserta didik sanggup membangkitkan partisipasi peserta didik dengan nyata yang ditunjukkan terhadap lingkungan melalui perilaku yang tumbuh atas dasar rasa kepedulian. Penelitian yang dilakukan menemukan hasil bahwa peserta didik memiliki rasa kepedulian dalam melestarikan lingkungan antara lain (1) peserta didik merawat tanaman yang telah ditanam dengan cara menyiram secara terus menerus, (2) sampah yang kedapatan berserakan diambil dan dibuang pada tong sampah, (3) peserta didik terjun secara langsung atau ikut berpartisipasi mengenai penghijauan di sekolah maupun masyarakat, dan (4) mengajak orang disekitar turut serta dalam kegiatan atau aksi pelestarian lingkungan. Keadaan tersebut menunjukkan peserta didik terhadap pelestarian lingkungan mempunyai partisipasi yang tinggi. Munculnya perilaku pelestarian lingkungan pada peserta didik dikarenakan pengetahuan mengenai lingkungan beserta fungsinya telah mereka dapatkan, sehingga sikap dan perilaku yang ditampakkan terhadap lingkungan amat baik. Hasil penelitian yang sejenis adalah penelitian (Istighfaroh, 2014); (Jannati, 2016); (Latipah, 2017); dan (Dewi, 2018) bahwa pembelajaran lingkungan berbasis kearifan lokal melalui observasi lapangan mampu meningkatkan kepedulian peserta didik dalam melestarikan lingkungan. Kepedulian peserta didik dalam melestarikan lingkungan diimplementasikan secara langsung dengan sikap dan perilaku yang dilakukan melalui aksi pelestarian lingkungan.

Pelestarian lingkungan pada kelas kontrol memiliki partisipasi yang berbeda. Perbedaan tersebut memengaruhi partisipasi pelestarian lingkungan pada kelas kontrol dengan skor partisipasi rendah dari kelas eksperimen dikarenakan guru menggunakan metode ceramah. Pembelajaran yang dilakukan hanya berlangsung didalam kelas dan peserta didik hanya mendengarkan materi yang banyak disampaikan oleh guru. Kegiatan belajar tersebut menjadikan sikap, perilaku dan keterampilan pembelajar lempem atau tidak dapat berkembang bahkan tidak aktif bila dihadapkan masalah yang nyata. 
Penelitian dengan hasil yang sama telah dilakukan oleh (Aini, 2014) menerangkan bahwa kurang terwujudnya sikap dan perilaku peduli lingkungan pada peserta didik dikarenakan proses belajar terpusat pada kognitif dan menghiraukan psikomotoriknya. Pembelajaran yang aktif dengan melibatkan peserta didik secara langsung didalamnya untuk berpikir dan mengembangkan keterampilannya dapat membentuk pribadi yang terdidik dalam segi sikap dan perilaku.

Pembelajaran konvensional menjadikan peserta didik kurang mendapatkan kesempatan untuk merasakan secara langsung dengan sumber belajar yang nyata terjadi pada kelas kontrol. Hal tersebut berakibat pada rendahnya partisipasi terhadap lingkungan. pada kelas kontrol terlihat pelestarian lingkungan hanya terjadi di dalam kelas. Selain itu, hasrat untuk berkecimpung terhadap pelestarian belum terlihat di lingkungan sekitar. Peneliti menemukan temuan bahwa gerakan memengaruhi orang sekitarnya untuk ikut serta dalam melindungi lingkungan tidak terlihat atau tidak nampak pad akelas kontrol.

\section{SIMPULAN}

Partisipasi peserta didik dalam pembelajaran lingkungan berbasis kearifan lokal menampakkan hasil kelas eksperimen lebih baik dibandingkan dengan kontrol. Keberhasilan tersebut disebabkan kelas eksperimen dan kontrol mendapat perlakuan yang berbeda. Kelas eksperimen diberi perlakuan Experiential Learning, sedangkan metode ceramah yang didominasi oleh guru dilakukan pada kelas kontrol.

Bentuk partisipasi peserta didik terhadap pembelajaran lingkungan berbasis kearifan lokal terbentuk melalui penyusunan artikel ilmiah dan melakukan aksi berdasarkan ide dalam artikel. Partisipasi peserta didik terhadap pembelajaran lingkungan berbasis kearifan lokal tersebut melingkupi pengendalian lingkungan sumber air di kampung Osing melalui kearifan lokal Osing yaitu acara selamatan, menjaga kebersihan lingkungan sekitar sumber air dengan mengambil dan membuang beberapa sampah yang berserakan disekitar sumber air untuk dibuang ditempatnya, dan melakukan penanaman tumbuhan berakar serabut yakni sengon untuk memperluas daerah resapan air, dan melakukan aksi-aksi peduli lingkungan lainnya.

Pendidikan seharusnya dilakukan dimanapun tidak melulu hanya pemberian teori didalam kelas, tetapi memanfaatkan lingkungan dan kearifan lokal sekitar sehingga terbentuk perilaku dan partisipasi dalam pembelajaran lingkungan berbasis kearifan lokal. Perilaku dan partisipasi seseorang seharusnya disimulasikan sejak dini terhadap pelestarian lingkungan. Proses pembelajaran dalam dunia pendidikan seharusnya mengaplikasikan kurikulum lingkungan. Selain itu, pendidik diarahkan untuk menggunakan metode pembelajaran agar proses pembelajaran mendukung. Model Experiential Learning merupakan metode yang tepat diantara metode yang lainnya dikarenakan dalam melestarikan lingkungan dengan pembelajaran lingkungan berbasis kearifan lokal dapat membentuk partisipasi peserta didik sehingga metode ini sangat direkomendasikan.

\section{DAFTAR RUJUKAN}

Afriani, A. (2018). Pembelajaran Kontekstual (Cotextual Teaching and Learning) dan Pemahaman Konsep Siswa. Jurnal Pendidikan Dasar, 3(1), 80-88.

Aini, M. H. (2014). Penguasaan Konsep Lingkungan dan Sikap Peduli Lingkungan siswa SMA Adiwiyata Mandiri di Kabupaten Mojokerto. Jurnal Biologi Edukasi, 3(3), 479-484.

Antika, R. R. (2014). Proses Pembelajaran Berbasis Student Centered Learning. Jurnal BioKultur, 3(1), 251-263.

Ardian, A. (2015). Pengaruh Strategi Pembelajaran Student Centered Learning dan Kemampuan Spasial terhadap Kreativitas Mahasiswa. Jurnal Pendidikan Teknologi dan Kejuruan, 22(4), 454-466.

Dewi, W. S. (2018). Pengaruh Model Pembelajaran Experiential Learning terhadap Motivasi Belajar Siswa pada Materi Ekosistem. Jurnal Biologi Ilmiah, 4(1), 14-17.

Fatliani, A. L. (2014). Pengaruh Model Pembelajaran Experiential Learning Terhadap Peningkatan Hasil Belajar IPA (Fisika) pada Siswa Kelas IX SMP Negeri 1 Marawola. Jurnal Pendidikan Fisika Tadulako, 2(4), 1-4.

Gunawan, R. (2014). Budaya Kearifan Lokal Dalam Tata Kelola dan Pengembangan Lingkungan Kota. Jurnal Sejarah dan Budaya, 1(2), 207-214.

Hariri, C. A. (2017). Penerapan Model Experiential Learning untuk Meningkatkan Pemahaman Materi Cahaya dan Sifatsifatnya. Jurnal Pendidikan dan Kebudayaan, 8(1),1-15.

Istighfaroh, Z. (2014). Pelaksanaan Model Pembelajaran Experiential Learning di Pendidikan Dasar Sekolah Alam Anak Prima Yogyakarta. Jurnal Teknologi Pendidikan, 2(2), 1-12.

Jannati, E. D. (2016). Model Pembelajaran Experiential Kolb untuk Meningkatkan Kemampuan Menjelaskan Fenomena Fisis Pada Konsep Optik. Jurnal Ilmiah Penelitian dan Pembelajaran Fisik, 2(2), 143-155.

Juairiah. (2014). Pembelajaran Berbasis Lingkungan untuk Meningkatkan Hasil Belajar Siswa pada Konsep Keanekaragaman Spermatophyta. Jurnal Biologi Edukasi, 6(2), 83-88.

Latipah, E. (2017). Pengaruh Strategi Experiential Learning terhadap Self Regulated Learning Mahasiswa. Jurnal Psikologi Indonesia, 14(1).

Maryuliana., Subroto I. M. I., \& Haviana, S. F. C. (2016). Sistem Informasi Angket Pengukuran Skala Kebutuhan Materi Pembelajaran Tambahan sebagai Pendukung Pengambilan Keputusan di Sekolah Menengah Atas Menggunakan Skala Likert. Jurnal Transistor Elektro dan Informatika, 1(2), 1-12. 
653 Jurnal Pendidikan, Vol. 4, No. 5, Bln Mei, Thn 2019, Hal 648-653

Pakpahan, D. R. (2017). Pengaruh Pengetahuan dan Sikap terhadap Perilaku Masyarakat di Wilayah Keluarahan Sei Sikambing. AT-TAWASSUTH: Jurnal Ekonomi Islam, 2(2), 345-367.

Sriyanto. (2007). Kondisi Lingkungan Hidup Jawa Tengah dan Prospek Pembangunan ke Depan. Jurnal Geografi, 4(2), 107113. 